The Revival of Scholastic Sacramental Theology after the Publication of Aeterni Patris
Irish Theological Quarterly 77(3) 265-285

(C) The Author(s) 2012

Reprints and permission: sagepub.co.uk/journalsPermissions.nav DOI: $10.1177 / 0021$ | 40012443760 itq.sagepub.com

@SAGE

\title{
Hector Scerri
}

University of Malta

\begin{abstract}
The article explores Neo-Scholasticism, a period in Catholic theology which, normally nowadays, attracts little attention. The publication of Leo XIII's encyclical Aeterni Patris, in 1879, and its effects on theology are studied with particular reference to sacramental theology. The main exponents of the Neo-Scholastic movement (e.g. Kleutgen, Mercier) and their contributions are highlighted. The article then proceeds to an in-depth analysis of the treatise De sacramentis in genere as presented by leading theologians, such as Franzelin, Billot, and van Noort. The central issue of causality is investigated. Finally, the article reflects briefly on the positive confluence between Neo-Scholasticism and Ressourcement in the first decades of the 20th century.
\end{abstract}

\section{Keywords}

Aeterni Patris, Billot, causality, Franzelin, Neo-Scholasticism, sacraments

$\mathrm{P}$ ope Leo XIII published his encyclical letter Aeterni Patris on 4 August 1879. This document is often considered to be a milestone, especially in the influence it was to exercise over theological reflection in the decades which followed. As one can see - and as is to be expected - the reaction to this document was quite mixed. Different quarters depict a varied response to Leo's aim at spreading Thomism in a philosophical context, which had become more and more pluralistic. A number of authors consider Aeterni Patris to be 'the starting point of the Scholastic Revival'

\footnotetext{
Corresponding author:

Hector Scerri, Dept of Fundamental \& Dogmatic Theology, Faculty of Theology, University of Malta, Msida MSD 2080, Malta.

[email: hector.scerri@um.edu.mt]
} 
in philosophy and theology. ${ }^{1}$ Others prefer to situate the encyclical within a process which owes its origins to a movement that was present in the early decades of the 19 th century.

In support of this latter trend, Cardinal Paolo Dezza holds that the encyclical was the spontaneous consequence of a gradual process in Catholic thought, a process which had its origins during the first half of the 19th century. After 1850, this process then matured at a more rapid pace as a result of the doctrinal controversies and debates which had then arisen. $^{2}$

\section{The Principles Enunciated in the Encyclical}

This section is not a summary of Aeterni Patris, but rather, gives some of the principal elements, which are more relevant to the general theme under study. ${ }^{3}$ In an effort to counteract modern trends in philosophy, Leo XIII advocates 'the right use of philosophy'; he praises the contribution of the Scholastics who 'diligently collecting, and sifting, and storing up ... [the] works of the ... Fathers' helped in 'confirming the dogmas of Catholic faith and confuting heresies." 4 The Pope praises the methods adopted by the Scholastic theologians in their reflection and asserts that they left a mark on future theological formulation because of their strong and firm philosophical foundations, which he contrasts with 'a lame and imperfect or vain philosophy. ${ }^{5}$ St Thomas Aquinas is praised from different angles, and his method strongly recommended. ${ }^{6}$ Referring indirectly to the movement that was already existent and which was attempting a revival of Aquinas and his whole system, Leo XIII asserts that

1 Gerald A. McCool, 'The centenary of Aeterni Patris,' Homiletic and Pastoral Review 79 (1978-79): 8-15, at 8. See Joseph De Finance, 'I grandi temi dell'enciclica,' in Tommaso d'Aquino nel I centenario dell'enciclica 'Aeterni Patris': Atti del convegno organizzato a Roma dalla Società Internazionale Tommaso d'Aquino e dalla Pontificia Università S. Tommaso d'Aquino, Roma 15-16-17 novembre 1979, ed. Benedetto D'Amore (Roma: Società Internazionale Tommaso d'Aquino, 1981), 49-70; Giuseppe Filograssi, 'Il commento del card. Francesco Ehrle all'enciclica Aeterni Patris di Leone XIII,' La Civiltà Cattolica 106 (1955): 659-664, at 661. Filograssi reviews Ehrle's commentary on the encyclical. This highly-praised commentary had been published in 1880, and was re-published in 1954 to commemorate the 75th anniversary of the encyclical. Aeterni Patris is here described as 'un punto di partenza, per collegare l'insegnamento di oggi a quello del secolo XIII e dell'Aquinate.'

2 See Paolo Dezza, Alle origini del neotomismo, Archivum Philosophicum Aloisianum 1 (Milano: Fratelli Bocca, 1940), 13.

3 For a sub-division of the themes and the relative sections of the encyclical, see D'Amore, Tommaso d'Aquino, 285-286.

4 Pope Leo XIII, 'Encyclical Letter on the Restoration of Christian Philosophy,' Aeterni Patris (trans. in Claudia Carlen, The Papal Encyclicals, 1878-1903 [New York: McGrath, 1981], 17-26), nos. 2, 14, and 15.

5 Ibid., no.16.

6 See ibid., nos.17-23. 
with wise forethought, therefore, not a few of the advocates of philosophic studies, when turning their minds recently to the practical reform of philosophy, aimed and aim at restoring the renowned teaching of Thomas Aquinas and winning it back to its ancient beauty. ${ }^{7}$

Continuing to praise Aquinas, Leo describes his contribution as the "purest streams of wisdom' containing 'wholesome doctrine ... in conformity with the teaching of the Church. ${ }^{, 8}$ The Pope concludes by exhorting bishops to restore the 'golden wisdom' of St Thomas, and to do their utmost to propagate it, in order to defend the faith against erroneous teaching; this can be attained by 'carefully selected teachers [who] endeavour to implant the doctrine of Thomas Aquinas in the minds of students, and set forth clearly his solidity and excellence over others.' 9

Reference has been made in the introduction to the way Aeterni Patris was received by various quarters. The negative reactions to the encyclical were not few in number. Leo XIII was accused of being instrumental in promoting a 'stagnation restricting the development of future thought or even ... a political move in the tradition established by Pius IX. ${ }^{10}$ Leo's stance was seen by others as representing a minority movement, which had arisen in Italy, as a reaction to Kantianism, Hegelianism, and other philosophical schools, which were not favourably accepted by the official Catholic position. ${ }^{11}$ Moreover, even certain Catholic circles failed to appreciate the Pope's intentions. ${ }^{12}$

It must also be said that the Catholic press did not remain passive. It staunchly defended the principles enunciated by the Pope in Aeterni Patris. This is evident in the literary style and form of expression used, for instance, in a series of articles which appeared in the Jesuit periodical La Civiltà Cattolica between August and November 1879. ${ }^{13}$

\section{The Theological Climate Prior to the Publication of the Encyclical}

Throughout the 19th century, the publication of theological manuals was at its height. The aim of this theological method was the presentation of Catholic doctrine in a way

7 Ibid., no. 25 .

8 See De Finance, 'I grandi temi dell'enciclica,' 53; Aeterni Patris, no. 26 and no. 28.

9 Aeterni Patris, no. 31.

10 J. Derek Holmes, 'Some English Reactions to the Publication of Aeterni Patris,' Downside Review 93 (1975): 269-280, at 270.

11 See Marcia L. Colish, 'St Thomas Aquinas in Historical Perspective: The Modern Period,' Church History 44 (1975): 433-449, at 445.

12 See Holmes, 'Some English Reactions,' 270-271.

13 See 'Cronaca Contemporanea,' La Civiltà Cattolica 11 (1879): 617-639; 'La regola filosofica di Sua Santità Leone P.P.XIII proposta nella enciclica Aeterni Patris,' La Civiltà Cattolica 11 (1879): 657-672; and the various instalments as follows: La Civiltà Cattolica 11 (1879): 165-183; La Civiltà Cattolica 12 (1879): 272-290; La Civiltà Cattolica 12 (1879): 425-443; La Civiltà Cattolica 12 (1879): 529-547. See also Roger Aubert, 'Le contexte historique et les motivations doctrinales de l'encyclique Aeterni Patris,' in D'Amore, Tommaso d'Aquino, $25-27,36$. 
that could be studied and learned, in particular, by those in preparation for the priesthood. The style of these manuals closely resembled the apologetic method, which had been created to offset the erroneous doctrines of the 16th-century Reformers. The manualistic framework consisted of long series of so-called theses. ${ }^{14}$ A notable example, which amply illustrates this way of presenting theological doctrine, is that formulated by Giovanni Perrone (1794-1876), an Italian Jesuit who taught dogmatic theology at the Collegio Romano (the Gregorian University) over a 30-year period from 1824 to 1853. He was also rector of the Collegio (1853-1855) and one of the theological experts at the first Vatican Council (1869-1870). His nine-volume work Praelectiones theologiae dogmaticae, published between 1835 and 1842, reached its 34th edition in 1888, while his Compendium, published in 1845, reached its 47th edition in 1892. Emphasis was put on the proofs obtained from Scripture and the Fathers, one of the aims being to thwart any rationalistic tendencies among lecturers and students. ${ }^{15}$ Avery Dulles seeks to give a balanced evaluation of the man, stating that 'Perrone's apologetic lacks nothing by way of clarity and logic, but it rests on narrow and uncriticized assumptions. His step-by-step movement from natural theology to Christian revelation, while highly suited to classroom presentation, fails to correspond to the actual process by which the mind progresses toward religious truth. 16

In this important period in the history of theology preceding Aeterni Patris, the German academic milieu was experiencing a particularly fertile and innovative renaissance. The contribution of the Tübingen School would exercise a remarkable influence on later theological reflection, especially in the 20 th century. ${ }^{17}$ Yet, this new approach to theology was treated with a measured degree of suspect and diffidence from official quarters. It sought to offer abundant theological reflection through the convergence of the respective riches of Scripture, the Fathers, and speculative thought. The main exponents of the Tübingen School were Johann Sebastian von Drey (1777-1853) and Johann Adam Möhler (1796-1838).

Drey, the founder of the School, was instrumental in setting the foundations of fundamental theology, writing a ground-breaking work-Die Apologetik als wissenschaftliche Nachweisung der Göttlichkeit des Christentums (Mainz, 1847) - that was praised for its recognition of the historical character of Christianity and for 'its organic view of tradition and of the Church.' ${ }^{18}$ Möhler contributed towards a renewal in ecclesiology, especially in his work Die Einheit der Kirche (Tübingen, 1825). He described the Church

14 For a schematic illustration of a thesis from a theological manual, see Carlo Rocchetta, Sacramentaria Fondamentale, 2nd ed. (Bologna: Dehoniane, 1990), 347.

15 Aubert has the following comment on Perrone: "non si distinse tanto per la sua opera scientifica, quanto per la volgarizzazione e polemica di fronte agli errori dell'epoca' (Roger Aubert, Storia della Chiesa, vol. 21/1, Il pontificato di Pio IX [1846-1878], 2nd ed. [Torino: Società Azionaria Internazionale, 1970], 298).

16 Avery Dulles, A History of Apologetics (San Francisco: Ignatius, 1999), 243.

17 See Franco Ardusso et al., Introduzione alla teologia contemporanea (Torino: Società Editrice Internazionale, 1972), 10-11; Jürgen Mettepenningen, Nouvelle Théologie - New Theology (London: T. \& T. Clark, 2010), 15-16.

18 Dulles, A History of Apologetics, 239. 
as a live reality. It was within this renewed ecclesiological framework that he described the sacraments as the vital organs of the Church. ${ }^{19}$ This presentation was to be found also in another of his works, Symbolik (Mainz, 1832). ${ }^{20}$ The pneumatological dimension, which had long been forgotten, found its way back into sacramental theology. Möhler asserted that the Church is nourished by the Holy Spirit; one of the ways in which this occurs is through the sacraments.

Another significant exponent of the German theological view in the period under study was Matthias Joseph Scheeben (1835-1888), author of the important work Die Mysterien des Christentums (Freiburg-im-Breisgau, 1865). Scheeben treated the fundamental dogmas of the faith as mysteries. Taking the sacramental nature of the Church as his foundation, his reflection on the sacraments led him to visualize them in the light of mysterion (mystery), a central concept in the patristic era. His forma mentis (frame of mind) in sacramental theology was an implicit reaction to the overemphasis on the notions of sign and causality. ${ }^{21}$ Scheeben's contribution was centred on the fact that the classical doctrine on sacramental efficacy could be pictured as a 'mystery,' which takes place within the Church. ${ }^{22}$

This glance at the 19th-century German theological context would be incomplete without a brief reference to the valuable input given by John Henry Newman (1801-1890). Newman was deeply appreciative of the sacraments, especially on account of his wide knowledge of the works of the Fathers. His general perspective shows a surprising similarity to the Tübingen School. ${ }^{23}$ He became particularly convinced about the role of the sacraments as effective signs of sanctification, and as a central feature of the Christian life. ${ }^{24}$

Reference has already been made to a Scholastic revival in the decades, which preceded the publication of Aeterni Patris. In part, this revival can be traced back to a number of German Catholic thinkers, such as Joseph Kleutgen (1811-1883) and Albert Stöckl (1832-1895). Kleutgen is often considered to be the mastermind behind the restoration of the use of the Scholastic method in German philosophical and theological quarters. This was part of his attempt to stem the tide caused by the erroneous doctrines of Georg Hermes (1775-1831), Anton Günther (1783-1863), and Jakob Frohschammer (1821-1893). By presenting afresh the tenets of a Catholic philosophy-especially against Kant, Hegel, and Schelling - he contributed to a revival in Scholasticism, especially in the light of Suárez. During the first Vatican Council, Kleutgen was the theological consultor to the bishop of Paderborn and was involved in the drafting of the conciliar constitution Dei Filius. In 1878, he was called to Rome to lecture in dogmatic theology at the Gregorian University. It is also often concluded that he was deeply involved in the drafting of Aeterni Patris. ${ }^{25}$ Nicknamed Thomas redivivus (Thomas come back to life),

19 See Rocchetta, Sacramentaria fondamentale, 349.

20 See Dulles, A History of Apologetics, 240.

21 See Rocchetta, Sacramentaria fondamentale, 349.

22 See Brunero Gherardini, 'Sul concetto di sacramento ieri e oggi,' Divinitas 19 (1975): 292334 , at 323.

23 See Ardusso et al., Introduzione alla teologia contemporanea, 11.

24 See Rocchetta, Sacramentaria fondamentale, 350.

25 See Fernand van Steenberghen, 'Les thomistes en dialogue avec la pensée moderne,' in D’Amore, Tommaso d'Aquino, 152; Mettepenningen, Nouvelle Théologie, 19. 
Kleutgen's contribution was highly precious because he was able to apply, with remarkable ease, the doctrine of the Scholastics to the debates of his time, while being, at the same time, outstandingly dexterous in raising critical questions with regard to Neo-Scholasticism. ${ }^{26}$

\section{Scholasticism in Early 19th-Century Italy}

Frederick Copleston agrees with Paolo Dezza's opinion - mentioned above - and asserts that 'it is not quite accurate to say that Leo XIII inaugurated the revival of Thomism. What he did was to give a powerful impetus to an already existing movement. ${ }^{27}$ There is abounding evidence for the activities of this movement. Carlo Rocchetta refers to the important contribution made by Italian thinkers such as Gaetano Sanseverino (18111865), Matteo Liberatore (1810-1892), Luigi Taparelli d'Azeglio (1793-1862), Giovanni Perrone (1794-1876), the brothers Domenico (1790-1880), and Serafino Sordi (17931865), and Vincenzo Buzzetti (1777-1824) whom Dezza calls the 'father of the neoThomist revival' in the city of Piacenza. ${ }^{28}$ Others prefer to evaluate the encyclical from within its historical context. In this latter case, Aeterni Patris is seen and understood as an affirmation of the ultramontane movement and a move towards centralization by Rome in philosophical and theological reflection, indeed an effort to curb 'flirtations with modern philosophy on the part of Catholic theologians. ${ }^{29}$

\section{The Propagation of Neo-Scholasticism after Aeterni Patris}

Following the publication of Aeterni Patris, one encounters a diverse movement in philosophy and theology whose guiding light is Scholasticism. This revival has had several effects. Copleston asserts that the movement led to the formation of what he calls 'a party-line, a kind of philosophical orthodoxy,' useful in defending the faith against thinkers who were considered to be more broad-minded and ready to accept other philosophical positions. ${ }^{30}$ A more positive feature - which ensues in the light of the Scholastic revival - is that the rediscovery of long-forgotten texts and schemes led to a vast amount of solid philosophical reflection.

26 See Aubert, 'Le contexte historique,' 15, 17, 21; see Dulles, A History of Apologetics, 239.

27 Frederick Copleston, A History of Philosophy, vol. 7 (London: Burns and Oates, 1963), 388389; also Frederick Copleston, A History of Philosophy, vol. 9 (London: Search, 1975), 250; Aubert, Storia della Chiesa, 301.

28 See Rocchetta, Sacramentaria fondamentale, 351; Giovanni Bortolaso, 'San Tommaso e l'enciclica Aeterni Patris: VIII Congresso tomistico internazionale (Roma 8-13 settembre 1980),' La Civiltà Cattolica 131 (1980): 67-70; Padre Dezza states that Taparelli 'domina il primo periodo della restaurazione scolastica che comprende la prima metà dell'ottocento $\mathrm{e}$ può chiamarsi il periodo della preparazione' (Dezza, Alle origini del neotomismo, 14).

29 Marcia L. Colish, 'St Thomas Aquinas in Historical Perspective,' 445; see also J. Derek Holmes, 'Some English Reactions,' 269-270.

30 Copleston, A History of Philosophy, vol. 9, 250. 
Even though one may come to the facile conclusion that plurality in philosophical and theological endeavour had become practically non-existent within Catholic academic circles after Aeterni Patris, Copleston insists that 'at no time indeed was Thomism as such imposed on Catholic philosophers in a way which would imply that it was part of the Catholic faith. ${ }^{31}$ Yet, it should be remembered that certain academic circles-and these were not few in number!-did attempt to present Thomism as the only method suited to Catholic theology. Different personalities and schools in this period exercised varying kinds of influence, depending on their way of presenting Thomism, their attitude to their listeners, and their approach to other systems of thought. Dezza states that the real intention of neo-Thomism was not merely a repetition of the doctrine of the Angelic Doctor and his contemporaries, but rather, a thorough re-examination of its principles with the aim of appreciating its original beauty - a splendour which had unfortunately been buried under countless commentaries and often imprecise interpretations of the original texts. Dezza holds that the immense richness of Scholastic philosophy and theology was to be presented in a manner which was comprehensible to modern men and women. $^{32}$

\section{The Impetus Given by Cardinal Mercier}

One of the central figures in the 19th-century Scholastic revival is Cardinal Désiré Joseph Mercier (1851-1926). ${ }^{33}$ At the publication of Aeterni Patris in 1879, Mercier had already been teaching philosophy at the Malines seminary in Belgium for two years. Within a few years, he was to become the first incumbent to the newly-established chair of Thomistic philosophy at Louvain. In 1888, Mercier founded the Philosophic Society of Louvain and, in 1894, this society started publishing the philosophical quarterly Revue néoscolastique de philosophie, which is still published today, though under a different title.

Mercier's name is closely associated with the correct interpretation of Aeterni Patris. As indicated earlier, the scope of this encyclical was often misinterpreted, both by those who faithfully adhered to its recommendations and by those who utterly rejected its proposals. Both a superficial reading of the encyclical and a staunch approach lead one to think that the document called for 'a return to the letter of thirteenth-century thought and ... sanction[ed] ... a particular philosophical doctrine. ${ }^{34}$ This was stated in an article which appeared in The Tablet, less than three weeks after the publication of the encyclical. It is indeed revealing to read that

31 Ibid.

32 See Dezza, Alle origini del neotomismo, 13-14; Ardusso et al., Introduzione alla teologia contemporanea, 11-12.

33 See Abelardo Lobato, 'Tomismo y antitomismo a lo largo de cien años,' in D'Amore, Tommaso d'Aquino, 101-136; Roger Aubert, 'Il risveglio culturale dei cattolici,' in Storia della Chiesa, vol. 22/2: La Chiesa e la societa`industriale (1878-1922), ed. Elio Guerriero and Annibale Zambarbieri (Milano: Paoline, 1990), 211-213.

34 The Encyclopedia of Philosophy, s.v. 'Mercier.' 
Aeterni Patris was not calling for the supremacy of Thomistic doctrine over other equally valid positions, but rather what was being recommended was Aquinas's method, his philosophandi ratio (way of doing philosophy). ${ }^{35}$ It is in this light that Mercier's contribution can be truly appreciated, namely, his role in the re-presentation of Thomistic philosophy in harmony with the latest developments in modern scientific reflection.

\section{Other Exponents of the Neo-Scholastic Movement}

Another important personality in the revival of Scholasticism in the context of post-Aeterni Patris instruction was Maurice De Wulf(1867-1947). He actively promoted this academic movement by indicating to his students at Louvain, where he taught for 46 years, the essence of Scholasticism, rather than restricting himself to a cosy framework provided by a collection of data and facts. Furthermore, De Wulf preferred the terms Scholasticism and Neo-Scholasticism to Thomism, which he considered to be too narrow terminologically, since it could not encompass the whole philosophia perennis (perennial philosophy) namely, the vast corpus of academic works elaborated by the 13th-century scholastics.

Other names inextricably bound with the Scholastic revival include Sertillanges, Garrigou-Lagrange, Billot, Maréchal, and more recently, Gilson and Maritain. AntoninDalmace Sertillanges (1863-1948), a Dominican preacher and apologist, endeavoured to apply the richness and the depth of the tenets of Thomism to various areas of thought; his more specialized field is the relation between philosophy and Christianity in the light of Aquinas. ${ }^{36}$ Sertillanges was also secretary of the Revue Thomiste in Paris. Reference has already been made to the Revue néoscolastique of Louvain. In fact, this period bears witness to the birth of several reviews and learned periodicals, whose aim was to spread far and wide the fruit of the research carried out by academics on Neo-Scholasticism in centres such as Paris, Louvain, and Rome. ${ }^{37}$

The great Dominican philosopher and theologian Réginald Garrigou-Lagrange (18771964 ) is a conspicuous figure in the period and for the process under study. Though he was often considered to be a rigidly staunch exponent of the neo-Thomistic line, his countless works and contributions - especially those spread over a period of more than half a century of teaching at the Angelicum University in Rome - are highly erudite and academic. ${ }^{38}$ His exposition is characterized by 'a forceful and clear exposition of the basic

35 The Tablet, 23 August 1879, 229-230 (as quoted by J. Derek Holmes, 'Some English Reactions,' 276). See De Finance, 'I grandi temi dell'enciclica,' 69; Bortolaso, 'San Tommaso e l'enciclica Aeterni Patris, 67-68; Bronislaw Dembowski, 'Reception of the Encyclical Aeterni Patris in Poland,' Collectanea Theologica 46 (1976): 187-203 [fasciculus specialis]. Dembowski distinguishes between two lines of interpretation, namely, ad mentem Thomae and secundum Thomae.

36 See Copleston, A History of Philosophy, vol. 9, 253-254.

37 See Lobato, 'Tomismo y antitomismo,' 108-9. Lobato mentions, among others, the following reviews: Divus Thomas, Rivista di filosofia neoscolastica, La Ciencia Tomista, Blackfriars, Doctor Communis, and New Scholasticism.

38 See Copleston, A History of Philosophy, vol. 9, 253. 
Thomistic insights,' which he studied with the help of the classical commentaries provided by Cajetan, Bañez, and Billuart. ${ }^{39}$ This is clearly evident in the way he developed the traditional treatises of dogmatic theology.

With Joseph Maréchal (1878-1944), a Belgian Jesuit, one encounters the development of so-called transcendental Thomism. Maréchal asserted that it is in Thomism that the fundamental problems of Kantianism find a solution. ${ }^{40}$ Etienne Gilson (1884-1978) presented Thomas Aquinas in his historical milieu, and, therefore, helps one to appreciate better the theological context in which his thought developed. One of Gilson's main contributions is the use of Thomistic philosophy as a hermeneutical criterion in understanding modern culture. ${ }^{41}$ Over against this, his contemporary Jacques Maritain (1882-1973) presents Thomism 'as an autonomous philosophy which can enter into dialogue with other philosophies without appealing to revelation. ${ }^{42} \mathrm{He}$ is often considered to be the chief exponent of the French group of 20th-century thinkers who promoted Thomism. Maritain opposed the use of the term neo-Thomism, which he considered as a misrepresentation of the true Thomistic approach, due to discrepancies between the latter and neoThomist views. In fact, Maritain once stated: 'I am not a neo-Thomist. All in all, I would rather be a paleo-Thomist than a neo-Thomist. I am, or at least I hope I am, a Thomist. ${ }^{, 43}$

\section{The Treatise De Sacramentis in Genere after the Publication of Aeterni Patris}

It is very interesting to consider - the principal aim of this article - the development in sacramental theology after the publication of Aeterni Patris. Having studied the events and the general situation leading to the encyclical, as well as having referred to the principal standard-bearers in the Scholastic revival, it is now apt to delve into the core of the issue. How did the publication of Aeterni Patris influence sacramental theology?

It practically goes without saying that all branches of theology were influenced by the development, which had already been taking place, and which was eventually strengthened by the position adopted by the magisterium of the Church. The implementation of what was called for in Aeterni Patris soon gathered momentum. One of the first effects consisted in the replacement of a number of professors, who were then lecturing in ecclesiastical universities in Rome and in other centres of learning. Some of the more significant changes took place at the Pontifical Gregorian University in Rome. ${ }^{44}$ What was the enduring significance of developments in Neo-Scholastic sacramental theology? Carlo Rocchetta sums these up when he mentions the value of returning to the Scholastic foundations of theology,

39 Encyclopedia of Philosophy, s.v. 'Garrigou-Lagrange.'

40 See Antonio Fontana, Teologi (Casale Monferrato: Piemme, 1994), 157-158.

41 See ibid., 101-102.

42 Copleston, A History of Philosophy, vol. 9, 254-255.

43 Jacques Maritain, Existence and the Existent (New York: Image, 1956), 1.

44 See Aubert, 'Il risveglio culturale dei cattolici.' Here, Aubert states that 'le riforme più incisive avvennero all'Università Gregoriana, particolarmente importante per il crescente numero di seminaristi stranieri che qui ricevevano la loro formazione' (Aubert, 'Il risveglio culturale dei cattolici,' 208); see also Aubert, 'Le contexte historique,' 42. 
namely, rediscovering its actual sources, and, consequently, overriding the eclectic style of a decadent Scholasticism. So many commentaries had been published over the centuries that the pristine beauty of the original Scholastic texts had been buried. Thus, the authentic contribution of Aquinas and his contemporaries could be appreciated. ${ }^{45}$

One of the great theologians of this period was Johannes Baptist Franzelin (18161886). Although his teaching career largely preceded the publication of Aeterni Patris, his theological position reflected a return to the Scholastic method, which had already been spreading primarily in Italy from the beginning of the 19 th century. ${ }^{46}$ From 1850 , Franzelin, a faithful disciple of Perrone, was lecturing in dogmatic theology in Rome. In 1857, he was appointed to the chair of dogmatic theology at the Gregorian University. Within a few years, he was successful in publishing an almost complete theology course, intended especially for his students. His De sacramentis in genere was first published in 1868; and his De Eucharistiae sacramento et sacrificio was published in the same year. Besides offering a more positive orientation in his presentation of dogmatic theology, Franzelin was also appointed consultor to various Congregations of the Roman Curia. He was heavily involved in the first Vatican Council (1869-1870), was appointed by Pius IX prefect of the Sacred Congregation of Rites, and made a cardinal in 1876, three years prior to the publication of Leo XIII's Aeterni Patris.

\section{Franzelin's De Sacramentis in Genere}

This research would be incomplete if it were not accompanied by a direct and tangible reference to some of the treatises on the general theology of the sacraments, published during this period. As stated previously, Franzelin's first edition of his De sacramentis in genere was published in 1868. A fifth edition was published in 1910. This shows that his theological schemes continued to be used and circulated long after his death, even despite the fact that the treatises by other professors were also available. This indicates the importance of his presentation of the sacraments.

Examining the list of the theses in Franzelin's Tractatus de sacramentis in genere reveals his use of the Thomistic framework. A glance at the analytical index of the treatise helps us to appreciate the quantity of direct references which Franzelin makes to Aquinas's treatment of the sacraments. This he does, for example, when developing the arguments relative to the causality of the sacraments, as well as in the section where he treats the minister's intention when administering the sacraments. ${ }^{47}$

Examining the 20 theses of Franzelin's De sacramentis in genere, one cannot fail to recognize a striking similarity to Aquinas's framework in the third part of his Summa. ${ }^{48}$ The following is a basic comparison - without entering into excessive detail — of Franzelin's text and the six quaestiones where Aquinas develops his De sacramentis in communi. ${ }^{49}$

45 See Rocchetta, Sacramentaria fondamentale, 350-351.

46 See ibid., 351.

47 See Ioannes Baptist Franzelin, Tractatus de sacramentis in genere, 5th ed. (Romae: Instituto Pii IX, 1910), 309.

48 See ibid., 297-298.

49 STh III 60-65. 
After an introductory first thesis bearing the title de notione generica et specifica sacramenti (on a general and specific notion of the sacrament), Franzelin - in theses II, III, and IV - dwells on the relationship between the sacraments novi testamenti (of the new dispensation) and their foreshadowing in the Old Law. References to the de relatione sacramentorum novi testamenti ad vetera (on the relationship of the sacraments of the new dispensation to those of the old) can be found in Aquinas's question 60 (articles 2 and 6); question 61 (article 3); question 62 (article 6); question 63 (article 1); and question 65 (article 1). The question of circumcision and the so-called sacramenti legis naturae (natural sacraments), which Franzelin treats in his third thesis, is discussed at length by Thomas in question 62 (article 6 ) and question 61 (article 3), respectively.

In thesis V, Franzelin discusses the question of matter and form as determined ab ipso institutore sacramentorum (by the very institutor of the sacraments). ${ }^{50}$ Aquinas treats this at great length in question 60 (articles 4, 5, 6, 7, and 8). The question on the form of the sacraments is taken up by Franzelin in thesis IX, where he dwells upon the consecratory effect of the words used during the administration of the sacraments. The discussion on sacramental causality ensues; the sacraments as causas instrumentales gratiae (an instrumental cause of grace) developed by Franzelin in his sixth thesis. The Angelic Doctor does this summarily in question 60 (article 1), and more fully in question 62 (article 4) and question 64 (articles 1 and 3 ). The discussion in Franzelin's sixth thesis is complemented by that in his tenth thesis on the sacraments as vera causa gratiae (a true cause of grace). This is in conformity with Thomas whose de necessitate sacramentorum (on the necessity of the sacraments) (question 61) can be understood more deeply while reading de effectu principali sacramentorum qui est gratia (on the principal effect of the sacraments, that is grace) (question 62). This leads to his consideration of de alio effectu sacramentorum, qui est character (on another effect of the sacraments, that is character) in question 63, treated by Franzelin in theses XII and XIII.

Several authors writing on the sacraments have attempted to classify the varying views regarding sacramental causality. ${ }^{51}$ On the one hand, non-Scholastic Catholic sacramental theology draws on concepts, which were central to patristic reflection on the sacraments. Emphasis was made on models such as eikon, typos and antitypos, homoioma, symbolon, mimesis, exemplum, similitudo, res, and signum (image, type and antitype, figure, symbol, imitation, example, likeness, object, and sign). ${ }^{52}$ On the other hand, causality was a central concept in Scholastic manuals on the sacraments. Pozzo highlights the fact that it is precisely on the issue of causality that the main contrast is to be identified between the manualistic presentation of the sacraments, and the theology of the sacraments in the context of the liturgical renewal of the first half of the 20th century. ${ }^{53}$

50 See Bernard Leeming, Principles of Sacramental Theology (London: Longmans, Green, 1956), 405-406.

51 See William A. Van Roo, De sacramentis in genere, 3rd ed. (Romae: Pontificia Universitas Gregoriana, 1966), 276; Leeming, Principles of Sacramental Theology, 283-301; Rocchetta, Sacramentaria fondamentale, 428-436.

52 See Franz-Josef Nocke, 'Dottrina generale dei sacramenti,' in Nuovo corso di dogmatica, ed. Theodor Schneider, vol. 2 (Brescia: Queriniana, 1995), 219-264, at 230-232.

53 See Guido Pozzo, 'La manualistica,' in Storia della teologia, vol. 3, ed. Rino Fisichella (Bologna: Dehoniane, 1996), 309-336, at 329. 
Franzelin adopts the view which has often been described as moral causality. ${ }^{54}$ According to this outlook:

the sacraments act as a moral cause acts, having in themselves a moral worth or value which moves God to give grace to their recipients. Thus, the connection between the sacrament and grace is not merely God's antecedent determination to give grace whenever the sacrament is administered, but is something in the sacrament itself ... Franzelin ... placed the moral worth of the sacraments in the fact that Christ himself is the principal minister. ${ }^{55}$

Theses VII and VIII regarding the efficacy of the sacraments ex opere operato (on the efficacity of the sacraments) are deeply related to theses XV, XVI, and XVII on the worthiness or unworthiness of the minister (de valore sacramentorum independenter a fide ac meritis ministry; on the value of the sacraments independently of the faith or merits of the minister) and his intention while administering the sacrament. ${ }^{56}$ Aquinas explains these features more or less conjointly in question 64 (articles 5, 6, 8, 9, and 10). In thesis XIV, Franzelin dwells upon Christ as institutore omnium sacramentorum (the institutor of all the sacraments); here, he draws on the second, third, and fourth articles of question 64 by Aquinas. In his three final theses (XVIII, XIX, and XX), Franzelin proceeds to a discussion on the number of the sacraments, an area often treated in the scholastic sentences, commentaries, and summae. Thomas devotes question 65 to this investigation.

From this overview, it is evident that Franzelin's theological scheme is basically Thomistic in its central and basic features. The areas treated - namely, 'sacraments' in the Old Law, matter and form, sacramental causality and grace, efficacy ex opere operato and the minister of the sacrament, institution by Christ and the number of the sacraments - are those which Aquinas covers in his consideration of de sacramentis in communi (on the sacraments in general). Franzelin's position is, for the most part, a continuation of that of Giovanni Perrone, his predecessor at the Gregorian University. ${ }^{57}$ Cipriano Vagaggini, in

54 See Van Roo, De sacramentis in genere, 287-293; Leeming, Principles of Sacramental Theology, 287-288, 297-301; Rocchetta, Sacramentaria fondamentale, 433-434. This trend owed its origins to Melchior Cano, M. Ledesma, and Francisco de Vitoria; it was further developed by G. Vazquez and especially by Cardinal de Lugo. Lessius, Pesch, Sasse, Mazzella, and Lennerz are among those who adhered to the trend.

55 Leeming, Principles of Sacramental Theology, 287, 298-299; Iohannes Baptist Franzelin, De sacramentis in genere (Taurini: Marietti,1868), 105-106; Iohannes Baptist Franzelin, De sacramentis in genere (Romae: Typis S. C. de Propaganda Fide, 1873), 106-107.

56 See Leeming, Principles of Sacramental Theology, 458, 459, 461.

57 It is worth mentioning that Franzelin started teaching dogmatic theology after the resignation of Carlo Passaglia as professor of dogmatic theology in 1857. In summary, this is the chronological sequence of the tenures of the professors of dogmatic theology at the Gregorian University: Giovanni Perrone (1824-53); Carlo Passaglia (1850-57); contemporaneously, one finds Clemens Schrader (1853-57) who was Passaglia's favourite disciple; Johann Baptist Franzelin was the disciple of Perrone and Passaglia (for further details on Passaglia, see Fontana, Teologi, 189-190). Fontana here asserts that 'metodologicamente Passaglia si distinse dalla tradizione neoscolastica per una maggiore attenzione alla Scrittura e ai Padri, che gli acconsentì di elaborare un'ecclesiologia — affina a quella di Möhler — volta a riscoprire la dimensione interiore della Chiesa, corpo mistico di Cristo,' a position adopted also by Schrader (Fontana, Teologi, 217). 
fact, describes Cardinal Franzelin as the 'continuator and perfecter of the concept of theology of Perrone and of the whole positive-scholastic tradition. ${ }^{58}$

\section{Billot's De Sacramentis in Genere}

Another important personality in the field of dogmatic theology during the period under study was Louis Billot (1846-1931), who like Franzelin was a Jesuit. After Billot had taught in France, Leo XIII had him called to Rome. He was professor of dogmatic theology at the Gregorian University from 1885 to 1910, when he was appointed consultor to the Holy Office. Billot laboured against the tide of Modernism, and was closely involved in the drafting of the encyclical letter Pascendi. Pius X created him a cardinal in 1911, an honour which he renounced in 1926. His position is ardently Thomistic; this is clearly evident from the texts of the dogmatic treatises upon which he lectured. ${ }^{59}$ In Billot and his contemporaries, one observes a strong sense of allegiance to Leo XIII and the Thomist revival; in fact, one notes a 'more purely scholastic concept of theology ... [which] was simply presented in the framework of direct commentaries on the Summa of St Thomas. ${ }^{, 60}$

Going through the texts of the theological manuals of this period, one discovers that there is a deeper and more marked contact with the actual text of Aquinas's Summa Theologiae than in other theological works of his time. This is very conspicuous in the structure of Billot's De sacramentis. In this treatise, Billot presents a commentary of the six quaestiones (60-65) already mentioned above, where Aquinas treats the general theology of the sacraments. In fact, the subtitles of Billot's text-Commentarius in 3am Partem S. Thomae - and a glance at the index are ample proof of this. ${ }^{61}$ Billot takes each quaestio and follows very closely the respective articles of the Summa. This is also evident in another theological work by Billot, De Ecclesiae sacramentis. Again, he subdivides his subject matter according to the Thomistic scheme, that is, following quaestiones 60-65 of the Third Part of the Summa Theologiae. Although the same basic structure is followed, one can immediately note a lengthier treatment of the subject matter; the headings of the subdivisions are also more detailed and indicative of the discussion. Furthermore, Billot's text is divided into theses and corollaries. ${ }^{62}$

It is also interesting to note that the opening lines of the prooemium (preamble) of Billot's De Ecclesiae sacramentis correspond precisely to the introduction which precedes question 60 of Aquinas's text. Aquinas begins his de sacramentis in communi (on the sacraments in general) by this introduction: 'Post considerationem eorum quae pertinent ad mysteria

58 Cyprian Vagaggini, Theological Dimensions of the Liturgy (Collegeville, MN: Liturgical, 1976), 555.

59 See Fontana, Teologi, 37; Aubert, 'Il risveglio culturale dei cattolici,' 208.

60 Vagaggini, Theological Dimensions of the Liturgy, 556.

61 See Ludovico Billot, De sacramentis. Commentarius in 3 am Partem S. Thomae, Pars prior (Romae: Pontificia Universitate Gregoriana, 1889-90), i-iii. The index is enumerated using Roman numerals and follows the epilogue.

62 Billot's methodology can be appreciated even by examining the index of this work (see Ludovico Billot, De Ecclesiae sacramentis. Commentarius in Tertiam Partem S. Thomae, tomus prior, 6th ed. [Romae: apud aedes Universitatis Gregorianae, 1924], 661-665). 
Verbi incarnati, considerandum est de Ecclesiae sacramentis, quae ab ipso Verbo incarnato efficaciam habent (Having considered the mysteries regarding the Incarnate Word, one now considers the sacraments of the Church which trace their efficacity to the Incarnate Word). ${ }^{63}$ Billot, without crediting Thomas, uses the same words; after the last phrase 'ab ipso Verbo incarnato efficaciam habent (which trace their efficacity to the Incarnate Word),' he adds: 'et ab eodem, curandis originalis et actualis peccati vulneribus fuerunt institute (and which were instituted by him to heal the wounds of original and actual sin). ${ }^{64}$

As in the presentation of Franzelin's contribution, even with Billot, one is obliged to refer to the polemic on sacramental causality. Billot's position differs from that of Franzelin. Billot was the first to propose the notion of intentional causality. ${ }^{65} \mathrm{He}$ asserts that moral causality is not sufficient in explaining the objective efficacy of the sacraments. ${ }^{66}$ Claiming to base himself on Thomas, Billot states that the causality of the sacramental sign can be described as intentional rather than physical. ${ }^{67}$ This causality, nonetheless, is instrumental, given that intentional causality is understood not only as a 'causa notificationis imperii (literally: a cause of notification of authority),' but also as 'causa rei notificatae (literally: a cause of the thing notified). ${ }^{68}$ Billot envisages the sacraments as a mediating cause of grace, inasmuch as their instrumental action is directly related to the operative capacity of the sacramental sign (vis instrumentalis intentionalis; the strength of the instrumental intention). ${ }^{69}$

Leeming's explanation in his own De sacramentis in genere helps to clarify Billot's position. The following are some of the more relevant notions, which lead to a better understanding of intentional causality as proposed by Billot:

(a) Billot rejects the idea of a spiritual force being subjected in the material elements of the sacraments; for the sacraments, being essentially signs, exist as such only in the significative order of realities and hence are incapable of carrying this 'physical' force ...;

(b) He insists that sacraments are 'practical signs' which verify their own meaning; when used by God their meaning is enhanced to enable them to do this. ${ }^{70}$

In order to clarify his illustration, Leeming gives examples of a juridical order. A will, for example, is an expression of a testator's intentions: it is the real instrument, which entitles the transfer to an heir of whatever property or belongings that the person possessed. Leeming

63 STh III 60.

64 Billot, De Ecclesiae sacramentis, 5.

65 See Billot, De Ecclesiae sacramentis, 116-143; Van Roo, De sacramentis in genere, 293-306; Thomas M. Pègues, 'De la causalité des sacrements d'après le R. P. Billot,' Revue Thomiste 11(1903): 689-708.

66 See Van Roo, De sacramentis in genere, 297-298.

67 Billot's theory met opposition from various quarters (see, for example, Floribert Struyf, 'La nouvelle théorie du R. P. Billot sur les sacrements,' Revue Augustinienne 6 [1905]: 35-53).

68 See Rocchetta, Sacramentaria fondamentale, 352-353.

69 See ibid., 353.

70 Leeming, Principles of Sacramental Theology, 337. See Rocchetta, Sacramentaria fondamentale, 435. 
distinguishes between this and other examples, on one hand, and the sacraments, on the other. In the example, the effect is something that exists only in the juridical order; this he calls 'an order of things which is essentially dependent upon human knowledge and human will. The sacraments, however, are Christ's expressions of his will and intention and thereby are effective. ${ }^{, 71}$ They communicate grace to those who are duly disposed, conferring upon them a claim to receive grace. According to this theory, the immediate effect of the sacraments is, therefore, not grace but a titulus appellans gratiam (a sign which attracts grace). This titulus is fulfilled by God, who endows and imbues the unhindering subject with grace. ${ }^{72}$

A central tenet upheld by Billot is that the sacraments significando causant (cause what they signify). ${ }^{73}$ This is clearly a reproposal of the Scholastic way of understanding sacramental causality. Scholastic sacramental theology understood the sacraments primarily as a means of achieving grace or, using Scholastic categories, as an instrumental cause of grace. The sacraments were defined as actions accomplished by Christ through the ordained minister, with the result that the person was transformed through the effects of grace, thereby achieving also an ontological union with Christ. As indicated earlier, the emphasis is on the individual's union with Christ; an ontological point of view predominates. ${ }^{74}$ As asserted above, in the period under study, the emphasis was on the sacraments as signs. ${ }^{75}$ This is in continuity with the Thomist position. Reference to those texts from the Summa indicated earlier reveals this important aspect. ${ }^{76}$

It has been stated that the sacraments are expressions of Christ's will and intention and are, thereby, effective. Billot also elaborates upon the manner in which Christ's will is indeed effective. Following the two points, (a) and (b) _Leeming's understanding of Billot - this scheme seeks to complete the latter's theory of intentional causality in sacramental theology:

(c) Billot is of the opinion that the words [uttered during the celebration of the sacraments] place an infallible ordination in the object which calls the divine power into operation... . Thus, in the Eucharist, the words of consecration make [what Billot calls] 'an infallible designation and ordination that by the divine power the elements be changed into the body and blood of Christ.'...

(d) [Talking about sacraments which confer a character], Billot distinctly says that the character in its physical reality is produced in exactly the same way as is grace, namely by an infallible designation that the divine power should produce it.

(e) [Finally, Billot states that] ... a special 'force' or power is added to the sacraments by God's institution, but it is such as is consistent with the nature of sacraments as signs ... [This force]

71 Leeming, Principles of Sacramental Theology, 338.

72 See Rocchetta, Sacramentaria fondamentale, 435.

73 See David N. Power, Unsearchable Riches: The Symbolic Nature of Liturgy (New York: Pueblo, 1984), 181.

74 See ibid., $180-181$.

75 In the 18th and 19th centuries, importance had shifted to the 'moral' or 'physical' causality of the sacraments. It was chiefly Billot's contribution which led to focusing on the symbolic reality of the sacraments (see Leeming, Principles of Sacramental Theology, 264-265).

76 See STh III 60.1-6; 61.1; 63.1-2; 64.2. 
... 'which by its own nature can do no more than signify, is lifted up to an effective application and investiture of its meaning., 77

Billot's contribution to sacramental theology was reproposed by several of his disciples, like the Dutchman Gerard Van Noort (1861-1946), Franz Diekamp (1864-1943) of Münster University, and Ludwig Lercher (1864-1937) of Innsbruck. It should also be noted that Billot's long academic career coincided with the Modernist crisis. So it is important to recall that his stance has to be seen and understood in the light of the historicotheological context in which he taught. The revival of Scholastic philosophy and theology throughout the 19th century, culminating in the publication of Aeterni Patris in 1879, was given a fresh impetus by the effort made to disprove the Modernist errors. Dulles explains that the Modernists 'were strongly influenced by various evolutionary, pantheistic, vitalistic, and pragmatistic currents in contemporary thought. They looked upon faith primarily as a feeling or experience rather than an adherence to any definable truth. ${ }^{, 78}$

The Modernists denied the immediate institution of the sacraments by Christ. They held that the sacraments are an interpretation, in no way absolute, of the mind of Christ by the nascent Church. Some of their opinions were heavily influenced by a Protestant notion of the sacraments. The Holy Office issued a decree entitled Lamentabili Sane on 3 July 1907, condemning the errors of the Modernists. The decree consisted of a list of 65 Modernist propositions. With regard to the sacraments, there are three such propositions:

39. The opinions on the origin of the sacraments with which the Tridentine Fathers were imbued and which undoubtedly influenced their dogmatic canons are far removed from those which are now rightly held by research historians of Christianity.

40. The sacraments owe their origin to the fact that the apostles and their successors interpreted some idea and intention of Christ under the influence and pressure of circumstances and events.

41. The purpose of the sacraments is only to recall to the mind of man the ever beneficent presence of the Creator. ${ }^{79}$

The latter Modernist proposition is described by Bernard Leeming as a mere repetition, yet in a more subtle manner, of the Protestant doctrine on sacramental efficacy. ${ }^{80}$ The polemic regarding the institution of the sacraments revolves around the word immediate. The Modernists held that, with the exception of Baptism and the Eucharist, Christ may have never thought of any of the other five sacraments; so they talked instead of a remote institution by Christ. Hence, the emphasis on the term immediate indicates that

77 Leeming, Principles of Sacramental Theology, 338-239. For a criticism of Billot's theory on intentional causality, see ibid., 341, 344.

78 Dulles, A History of Apologetics, 277. See Mettepenningen, Nouvelle Théologie, 20-22.

79 Jacques Dupuis, ed., The Christian Faith in the Doctrinal Documents of the Catholic Church (Bangalore: Theological Publications in India, 2001), no. 1326.

80 See Leeming, Principles of Sacramental Theology, 27. 
it is not merely by Christ's authority, nor merely as an interpretation of his mind, that a sacrament is to be conceived; but that a sacrament must be referred to Christ himself as the one who determined the essence of the sacrament, however that essence, or substance, be conceived. ${ }^{81}$

In his commentary on De causa sacramentorum, Billot asserted that the sacraments are ' $a b$ eo [i.e. by Christ] immediate institute (directly instituted). ${ }^{, 82}$ This point of discord featured again in the encyclical letter Pascendi Dominici Gregis, published by Pius X on 8 September 1907, barely two months after the decree Lamentabili. In this encyclical, the Pope condemned the Modernist assertion, which held that the sacraments, as all that belongs to the area of cult, have only a symbolic value. ${ }^{83}$ Again, the polemic regarding the immediate institution of the sacraments by Christ was brought up. ${ }^{84}$ Thus, while recalling the untiring efforts of his predecessor, Leo XIII, Pius X urges that 'Scholastic philosophy be made the basis of the sacred sciences ... And ... let it be clearly understood above all things that the Scholastic philosophy we prescribe is that which the Angelic Doctor has bequeathed to us. ${ }^{85}$

In the light of what has been said above concerning the institution of the sacraments, the Modernists and their adherents even upheld the existence of a relationship between the sacraments and pagan mystery rites, going even to the extent of claiming that the sacraments were in fact derived directly from the pagan cults through an evolving process of purification and christianization. ${ }^{86}$ Such claims led to a Catholic reaction, which has already been described. It was also in this context that the Dominican Ambroise Gardeil (1859-1931) wrote his renowned work La Crédibilité et l'apologétique which appeared in $1908 .^{87}$ Every cloud has a silver lining: this turbulent theological context was conducive in stimulating Catholic academics to return to the biblical, patristic, and liturgical sources - the providential ressourcement of the first half of the 20th century. However, it is worth noting that the De sacramentis in genere, first published by Franzelin in 1868 , had already sought to forge a confluence between the Scholastic tradition and patristic sacramental theology. ${ }^{88}$

81 Ibid., 395.

82 See STh III 64.1-4. It is worth noting that an examination of this text speaks explicitly of the fact that institutio sacramentorum sit solum a Deo (article 2). With regard to those things which belong de necessitate sacramenti, these are ab ipso Christo instituta, qui est Deus et homo (article 2). In article 3, Thomas asserts that because the sacraments derive their power from their institution it is a property of the excellence of Christ's power that he himself potuit instituere sacramenta (had the power to institute the sacraments). In the introduction to thesis XV, Billot's commentary talks about the immediate institution of the sacraments by Christ. In the third section of this same thesis, Billot asserts that the sacraments are ' $a$ Christo immediate instituta' (Billot, De Ecclesiae sacramentis, 171-176).

83 See Dupuis, The Christian Faith, no. 1327.

84 See Leeming, Principles of Sacramental theology, 395.

85 Pope Pius X, 'Encyclical Letter on the Doctrines of the Modernists, Pascendi Dominici Gregis,' in The Papal Encyclicals, 1903-1939, trans. Claudia Carlen (New York: McGrath, 1981), no. 45.

86 See Rocchetta, Sacramentaria fondamentale, 351.

87 See Dulles, A History of Apologetics, 279-280.

88 See Rocchetta, Sacramentaria fondamentale, 351. 


\section{Van Noort, Lennerz, and Garrigou-Lagrange}

In examining Aeterni Patris and its effect on the presentation of sacramental theology, it is useful to refer to a number of other theological manuals, which were in use throughout the first half of the 20th century. Franzelin's and Billot's manuals were not the only ones in use; they inspired other theologians to compile their own textbooks.

Gerard van Noort's opus consists of two volumes. Nearly one-third of the first volume is devoted to an exposition of his De sacramentis in genere. ${ }^{89}$ Van Noort (1861-1946) was professor of dogmatic theology at the Faculty of Theology in Warmond, Holland, from 1892 to 1908. It was there that he completed a valuable ten-volume work on dogmatic theology, entitled Tractatus apologetici et dogmatici (Leyden, 1898-1908), which was later revised by J.P. Verhaar, a theology professor at the same faculty.

Examining van Noort's De sacramentis in genere, one sees that the Thomistic sequence is followed, though conspicuously more loosely than Franzelin and Billot. The general structure is:

I. De sacramentorum exsistentia et partibus (definition and distinctions);

II. De sacramentorum efficacia (causality, grace, character);

III. De sacramentorum causis (institution, the minister, the subject);

IV. De sacramentis ante Christum et de Sacramentalibus.

Going through the pages of this textbook, one is immediately struck by the vast number of footnotes. The content of these footnotes reveals the breadth of the sources which van Noort uses: Scripture, the Fathers, the Summa of St Thomas, the decrees of synods and councils, papal documents, the monumental works of other authors who had written their own De sacramentis, and articles in periodicals and reviews. Van Noort's work offers an intelligent compendium, which was widely used up to recent decades.

Van Noort follows the position held by Billot regarding intentional causality. ${ }^{90}$ With reference to the discussion on the grace conferred by the sacraments, van Noort can be placed in the same category as Cajetan, Suárez, and de Lugo, who all refer to the Thomistic understanding of auxilium (help). With them, van Noort envisages sacramental grace as consisting 'in a claim to the various actual graces which are signified by the sacrament which is conferred or in the attainment of the end for which the sacrament has been instituted.' 91

Heinrich Lennerz (1880-1961) was professor of dogmatic theology at Valkenburg from 1914 to 1925, and subsequently, at the Gregorian University in Rome. ${ }^{92}$ Opening

89 See Gerard van Noort, Tractatus de sacramentis, vol. 1 (Bussum, Holland: sumptibus Societatis anonymae Pauli Brand, 1927), 1-123, 407.

90 See Rocchetta, Sacramentaria fondamentale, 353, 434-435.

91 'in un diritto alle diverse grazie attuali significate dal sacramento conferito o per il raggiungimento del fine per il quale esso è stato istituito' (Rocchetta, Sacramentaria fondamentale, 486).

92 See 'In memoriam,' Gregorianum 43 (1962): 87-88. 
his De sacramentis novae legis in genere, one finds that in the introduction he commences by referring to the Incarnation and Redemption; he then proceeds to refer to the Catholic Church, whose task it is to communicate the fruits of Redemption to all. ${ }^{93}$ The introduction also contains a section on the 16th-century errors regarding the sacraments. Here, Lennerz refers to the doctrinal positions of Luther, Melanchton, Zwingli, Calvin, and the Confessio Augustana, and rebuts them by presenting the Tridentine doctrine. ${ }^{94}$

The same themes are treated by Lennerz as in the De sacramentis in genere of other theologians, although he presents them in a different sequence. At the beginning of most theses, he generally gives a bibliography, and here, the more common references are to Peter Lombard, Aquinas, Franzelin, Billot, Pesch, and De Smet, though he occasionally also refers to Suárez, de Lugo, and Bellarmine.

The synthesis offered by Réginald Garrigou-Lagrange (1877-1964) — as one would expect-follows the Thomistic exposition with great fidelity. This can be seen in his presentation of the general themes of sacramental theology. He affirms that the sacraments are efficacious signs of grace. Sacraments confer grace ex opere operato; this occurs, he asserts, by means of a physical, instrumental causality. Garrigou-Lagrange comments that the term physical is not to be found in Aquinas, who affirms that the instrumental causality is actual and does not pertain to the moral order. ${ }^{95}$

Garrigou-Lagrange refers also to the Scholastic doctrine of the matter and the form of the sacraments, and here recalls the important contributions of William of Auxerre and Alexander of Hales. Garrigou-Lagrange speaks of the matter and form of Baptism, Penance, and Marriage (where he refers to the Commentarium in quattuor libros Sententiarum). He then dwells briefly on the institution of the sacraments by Christ. Finally, Garrigou-Lagrange remarks that the sacraments can be seen in an analogy to human life. He states that in the natural order, human beings receive life, grow, require sustenance, and, at times, require healing and restoration. On the supernatural level, these phases correspond to Baptism, Confirmation, the Eucharist, Penance, and the Anointing of the sick. On the social plane, human beings exercise a particular duty or function. In the supernatural order, this is realized through the sacraments of Marriage and Orders. ${ }^{96}$

\section{Vonier: A Convergence between Neo-Scholasticism and Ressourcement}

The part played by the Benedictine monk, Dom Anscar Vonier (1875-1938), represents an important point of convergence between the Scholastic revival in sacramental theology and the Return to the Christian Sources Movement (Ressourcement). In fact, the

93 See Heinrich Lennerz, De sacramentis novae legis in genere, 3rd ed. (Romae: aedes Universitatis Gregorianae, 1950), 1-20.

94 See ibid., 4-12.

95 See Réginald Garrigou-Lagrange, La synthèse thomiste (Paris: Desclée de Brouwer, 1947), 383.

96 See ibid., 384-385. 
maturation of his reflections and the publication in 1925 of his work, A Key to the Doctrine of the Eucharist, represent those years when scholars like Romano Guardini (1885-1968) and another Benedictine monk, Dom Odo Casel (1886-1948) were opening new fields through their innovative theological presentations. The early years of the 20th century were polarized by various discussions on the nature of the Mass. It is sufficient to mention the works by Maurice de la Taille, a professor at the Gregorian University in Rome, and M. Lepin, a professor at the Lyons Seminary, in order to get a sense of the prevailing situation. $^{97}$

Vonier explains that the Mass is not a natural sacrifice, but a sacramental sacrifice. In so doing, he goes to the very foundation of the notion of sacrament: he elaborates on the fact that the sacraments are primarily signs of the passion and the glorification of our Lord. ${ }^{98}$ It is only consequent to this fact that sacraments are to be understood as signs of grace. It is also in this light that two inextricable aspects of the sacraments are to be seen: namely, that they are acts of worship and means of sanctification. ${ }^{99}$ Vonier's position is very close to that proposed by Odo Casel, in his Mysteriengegenwart theory. This theory affirms that Christ's mysteries are present during the celebration of the sacraments. Furthermore, these mysteries are not only symbolically represented, but they 'are made present truly, actually, and effectively., 100

These are only some of the aspects heralding the beginning of a process, which was to lead theologians to take the limelight from the debate on sacramental causality. ${ }^{101}$ Yet, despite the new emphases which were made by the mid-20th century, the Neo-Scholastic explanation of causality remained a central theme in the study of the sacraments. ${ }^{102}$ Eventually, other aspects of the richness which characterizes sacramental theology began to be appreciated: for example, the relationship between the Paschal mystery and the celebration of the sacraments. The reference to Dom Anscar Vonier's contribution serves to throw light on the important bridge between, on the one hand, the Scholastic revival and Aeterni Patris, and, on the other, the Return to the Christian Sources Movement in the first half of the 20th century. Even though his more important contribution concerns the sacrament of the Eucharist, the role he played in the development of a renewed environment in theological reflection on the sacraments is to be highly appreciated. Regis Duffy's

97 Mauritius de la Taille, Mysterium fidei, 3rd ed. (Paris: Gabriel Beauchesne, 1931). The two previous editions had been published in Paris in 1921 and 1924; Marins Lepin, L'idée du sacrifice de la Messe d'après les théologiens depuis l'origine jusqu'à nos jours (Paris: Gabriel Beauchesne, 1926).

98 See Colman E. O'Neill, 'I Sacramenti,' in Bilancio della Teologia del XX Secolo, III, ed. Robert Vander Gucht and Herbert Vorgrimler (Roma: Città Nuova, 1972), 268; Power, Unsearchable Riches, 181.

99 See Anscar Vonier, A Key to the Doctrine of the Eucharist (London: Burns, Oates \& Washbourne, 1925), 46-47; Rocchetta, Sacramentaria fondamentale, 354; Leeming, Principles of Sacramental Theology, 307-310.

100 Ibid., 309.

101 See O'Neill, 'I Sacramenti,' 269.

102 See Pozzo, 'La manualistica,' 329. 
evaluation offers an insight into the confluence of the Scholastic revival and ressourcement in his work:

in a refreshing retrieval of Thomas's teaching on sacramental signification, Vonier argued for the ecclesial dimension of sacrament and for the notions of liturgy and banquet in speaking of Eucharist. Though this seems commonplace now, a comparison of Vonier's work with the usual sacramental tracts of the manuals will confirm this theologian's unique contribution at the time. $^{103}$

It is in this context that one situates the precious contribution - in the first half of the 20th century - of the principal exponents of the Liturgical Movement to the development of sacramental theology, and to the rediscovery in ecclesiology of the Church as corpus mysticum (the mystical body). These are important milestones on the path to the opening, 50 years ago, of the Second Vatican Council.

\section{Author Biography}

Hector Scerri is Head of the Department of Fundamental and Dogmatic Theology at the University of Malta, where he lectures on Christology, Mariology, Eschatology, and the Sacraments. He lectures on Christian Anthropology at the Major Seminary of the diocese of Gozo. He is President of the Interdiocesan Theological Commission (Maltese Episcopal Conference) and the Diocesan Ecumenical Commission (archdiocese of Malta).

103 Regis A. Duffy, 'Sacraments in General,' in Systematic Theology, vol. 2, ed. Francis Schüssler Fiorenza and John P. Galvin (Minneapolis: Fortress, 1991), 183-210, at 201. 